\title{
The potassium level in the blood of sheep and their productivity
}

\author{
Czeslawa Lipecka, M. Pięta and T. Gruszecki \\ Institule of Animal Breeding and Technology of Animal Production, \\ Lublin Agricultural University \\ Akademicka 13, 20-950 Lublin 1, Poland
}

(Received 9 July 1993; accepted 12 May 1994)

\begin{abstract}
The production value of sheep having a high or low blood potassium level were investigated. The $\mathbf{K}$ level in the whole blood of the five month old lambs was determined and classified into the respective phenotype: $\mathrm{LH}$ and HK. The study were carried out on 871 lambs and 312 ewes.

In the tested population, the frequency of gene $\mathrm{K}^{11}$ in lambs was 0.427 , whereas in ewes 0.540 . The average level of potassium in blood in 5 month old lambs was found to be $30.5 \mathrm{mmol} / \mathrm{l}$ in the HIK phenotype and $9.3 \mathrm{mmol} / \mathrm{l}$ in the LH phenotype. The results also showed that potassium-determined phenotypes had similar body weight after birth $(5.1 \mathrm{~kg})$, at the age of $28(13.3)$ and 100 days $(30.0 \mathrm{~kg})$, and at 12 months $(72.3 \mathrm{~kg})$. The ewes had also an approximate yield of greasy wool both from the first (about $4.5 \mathrm{~kg}$ ) and second $(6.7 \mathrm{~kg}$ ) shearing performed at the age of 10 and 22 months. A significantly lower fertility and reproduction performance was found in ewes of the HK phenotype.
\end{abstract}

KEY WORDS: sheep, blood, potassium level, growth, reproduction

\section{INTRODUCTION}

In the previous works it has been stated that the potassium blood level in sheep is genetically controlled by two alleles $\mathrm{K}^{\mathrm{I}}$ and $\mathrm{K}^{\mathrm{H}}$, the second one recessive (Agar et al., 1972; Bhat et al., 1981; Bojczuk, 1987; Kumar, 1984; Lazovski and Spiridonov, 1974; Lipecka et al., 1987; 1991). Homozygotes of the $\mathrm{K}^{\mathrm{H}}$ gene are characterized by a high potassuim level in blood (level HK), while those of the $\mathrm{K}^{\mathrm{L}}$ gene and heterozygotes by a low potassium blood level (level LK). These studies have also proved that there is a considerable differentiation between breeds, kinds, and even a differentiation within a breed between flocks in the frequency 
of occurrence of genes and phenotypes. Simultaneously the potassium level is reflected in differentiated physiological and biochemical changes (Agar et al., 1972). This can affect the productivity level of animals, constituting a certain selective index.

The aim of the present paper was to determine the influence of potassium blood level in Polish Lowland sheep on the growth of lambs, wool productivity and features of reproduction.

\section{MATERIAL AND METHODS}

The studies concerned lambs and their mothers born in the years 1981-1990 in one farm in which the feeding and environmental conditions in each experimental year were similar.

The potassium level in the whole blood of the month old lambs was determined with the use of the atomic absorption spectrophotometr according to the method described by Lipecka et al. (1987). The classification into the respective phenotype: HK or LK was performed simultaneously. All of the individuals having a high potassium blood level (HK) and, in order to diminish the disproportion in the number between the both phenotypes, only their half sibs with a low potassium level (LK) were taken for the analysis. In case of lambs, the animal material had not been selected and comprised all together 1065 lambs (473 rams and 592 ewes). The mothers (312 sheep) originated from the reproduction flock.

To determine the influence of the potassium level on the performance traits, separately for the sexes, the analysis of variance according to the least squares was made (Harvey, 1989). In the statistical model the age group, the type of birth and the potassium level phenotype was regarded.

\section{RESULTS}

The potassium level in the investigated population of lambs ranged from 6.88 to $43.5 \mathrm{mmol} / 1$ in the rams, and from 5.87 to $38.75 \mathrm{mmol} / 1$ in the ewes (Fig. 1). Generally, for all the age groups of rams and ewes the average potassium level for the LK phenotype was $9.74 \pm 4.98$ and $8.86 \pm 3.59 \mathrm{mmol} / 1$, respectively for the sexes, while the values for the HK phenotype were $30.74 \pm 8.03$ and $30.35 \pm 7.55$ $\mathrm{mmol} / \mathrm{l}$.

The body weight of rams controlled after birth, as well as at the age of 28 and 100 days and 12 months did not differ significantly between the groups of low and high potassium level in the blood. Significant differences were not found for 


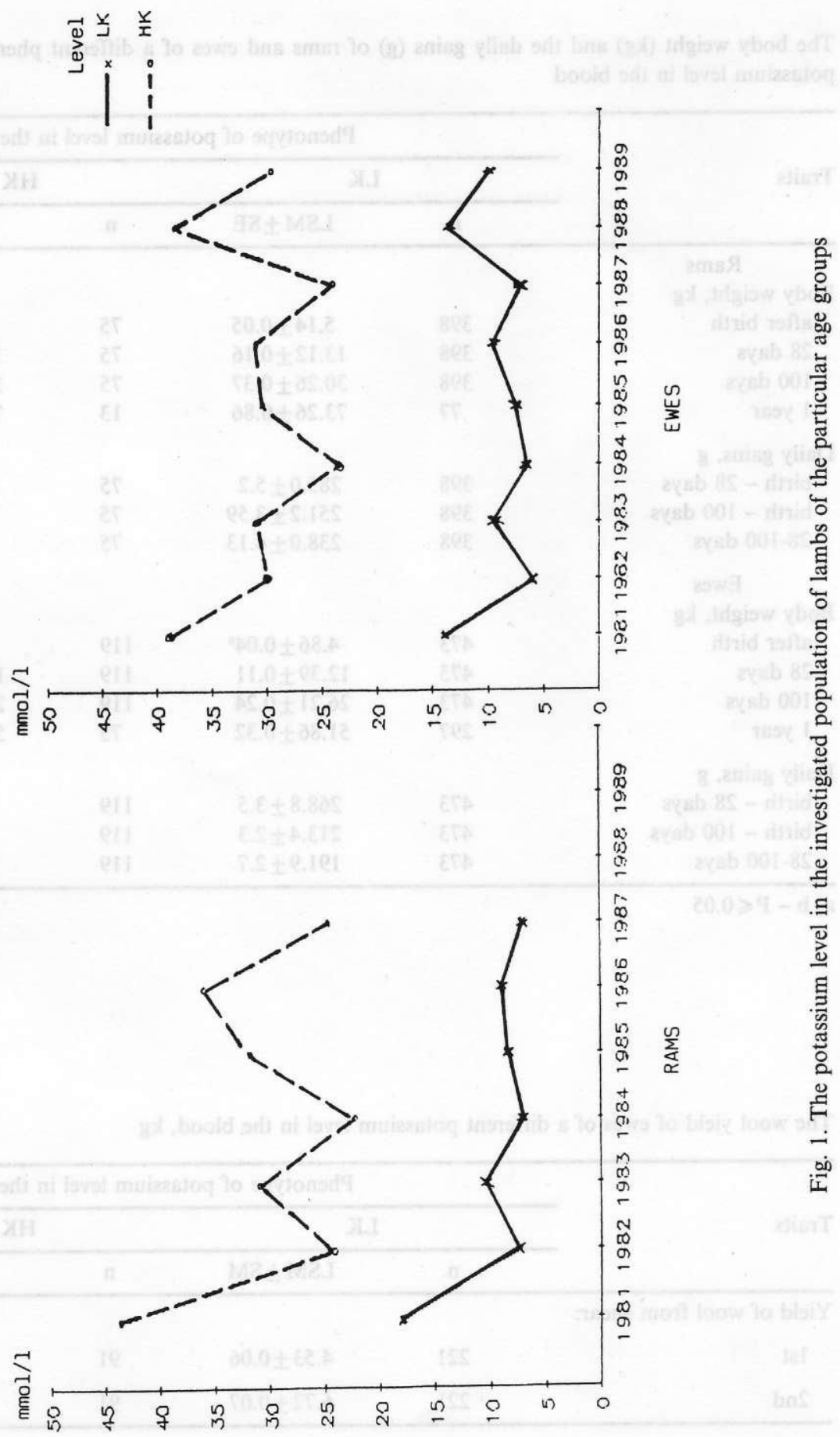


TABLE 1

The body weight $(\mathrm{kg})$ and the daily gains $(\mathrm{g})$ of rams and ewes of a different phenotype of the potassium level in the blood

Phenotype of potassium level in the blood

Traits

\begin{tabular}{ccccc}
\hline \multicolumn{2}{c}{ LK } & \multicolumn{3}{c}{ HK } \\
\hline $\mathrm{n}$ & $\mathrm{LSM} \pm \mathrm{SE}$ & $\mathrm{n}$ & $\mathrm{LSM} \pm \mathrm{SE}$ \\
\hline
\end{tabular}

Rams

Body weight, kg

after birth

28 days

100 days

1 year

Daily gains, $\mathrm{g}$

birth - 28 days

birth - 100 days

28-100 days

Ewes

Body weight, $\mathrm{kg}$

after birth

28 days

100 days

1 year

Daily gains, $\mathrm{g}$

birth - 28 days

birth -100 days

28-100 days

$\mathrm{a}, \mathrm{b}-\mathrm{P} \leqslant 0.05$

$\begin{array}{rrrr}398 & 5.14 \pm 0.05 & 75 & 5.13 \pm 0.10 \\ 398 & 13.12 \pm 0.16 & 75 & 13.51 \pm 0.30 \\ 398 & 30.26 \pm 0.37 & 75 & 29.79 \pm 0.68 \\ 77 & 73.26 \pm 0.86 & 13 & 71.51 \pm 2.03\end{array}$

$\begin{array}{llll}398 & 285.0 \pm 5.2 & 75 & 299.5 \pm 9.5 \\ 398 & 251.2 \pm 3.59 & 75 & 246.6 \pm 6.6 \\ 398 & 238.0 \pm 4.13 & 75 & 226.0 \pm 7.6\end{array}$

473

473

473

297

473

473

473
$4.86 \pm 0.04^{a}$

$12.39 \pm 0.11$

$26.21 \pm 0.24$

$51.86 \pm 0.32$

$268.8 \pm 3.5$

$213.4 \pm 2.3$

$191.9 \pm 2.7$
119

119

119

75

119

119

119
$5.02 \pm 0.07^{\mathrm{b}}$

$12.43 \pm 0.20$

$26.28 \pm 0.41$

$52.05 \pm 0.59$

$264.5 \pm 6.2$

$212.6 \pm 3.9$

$192.4 \pm 4.6$

TABLE 2

The wool yield of ewes of a different potassium level in the blood, $\mathrm{kg}$

\begin{tabular}{lcccc}
\hline & \multicolumn{4}{c}{ Phenotype of potassium level in the blood } \\
\cline { 2 - 5 } Traits & $\mathrm{n}$ & LS & $\mathrm{n}$ & HK \\
\cline { 2 - 5 } & & & & LSM \pm SE \\
\hline Yield of wool from shear: & 221 & $4.53 \pm 0.06$ & 91 & $4.44 \pm 0.08$ \\
1st & 221 & $6.72 \pm 0.07$ & 91 & $6.74 \pm 0.09$ \\
2nd & &
\end{tabular}


the daily gains, either. Similar results were obtained for the the ewes, except that the body weight after birth turned to be higher in the individuals with a high potassium level in the blood (Table 1).

The mothers of both potassium level phenotypes had an approximate yield of greasy wool, both from the 1st and 2nd shear (Table 2). Fecundity - FC (the number of born lambs in relation to the number of lambed ewes), as well as reproductive performance - RP (the number of reared lambs in relation to the number of mated ewes) in the three successive reproduction cycles did not differ significantly between the groups. A lower fertility - FT (the number of lambed mothers in relation to the number of the mated ones) was characteristic for the mothers with the HK phenotype in relation to the half sisters of the LK phenotype in the 1st and 2 nd lambing (Fig. 2). The analysis of the whole-life reproduction indices has shown that lower fertility was characteristic for the ewes with the $\mathrm{K}^{\mathrm{H}}$ recessive in the homozygotic form $-87.4 \%$ in relation to those with $\mathrm{K}^{\mathrm{L}}$ gene, both in homo- and heterozygotic form $-95.8 \%$. Also the reproductive performance of the ewes of the HK phenotype was lower by 8.9 per cent units (Table 3).

\section{DISCUSSION}

The studies carried out have proved that lambs of both potassium level phenotypes had approximate body weight in all the analyzed growth periods. The daily gains were also similar. These findings confirm the data described by Kumar (1984). Atroshi (1979) stated that the lambs of both phenotypes, despite their similar weight at birth, differ in their daily gains; slightly higher daily gains were recorded in lambs of the LK phenotype. Watson and Khattab (1964) found that lambs of the LK phenotype have higher body weight after birth and they grow faster. On the other hand, Atroshi (1979) points to a higher wool

TABLE 3

A total-life reproductive traits of ewes with different potassium level in the blood

Phenotype of potassium level in the blood

\begin{tabular}{lcccc}
\hline & \multicolumn{4}{c}{ Phenotype of potassium level in the blood } \\
\cline { 2 - 5 } Traits & \multicolumn{2}{c}{ LK } & \multicolumn{2}{c}{ HK } \\
\cline { 2 - 5 } & $\mathrm{n}$ & $\mathrm{LSM} \pm \mathrm{SE}$ & $\mathrm{n}$ & $\mathrm{LSM} \pm \mathrm{SE}$ \\
\hline Fertility & 221 & $95.8 \pm 1.7^{\mathrm{A}}$ & 91 & $87.4 \pm 2.2^{\mathrm{B}}$ \\
Fecundity & 221 & $131.9 \pm 3.5$ & 91 & $128.6 \pm 4.6$ \\
Reproductive performance & 221 & $118.2 \pm 3.6^{\mathrm{a}}$ & 91 & $109.3 \pm 4.7^{\mathrm{b}}$ \\
\hline
\end{tabular}

$a, b-P \leqslant 0.01 ; A, B-P \leqslant 0.05$ 


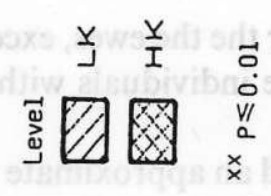

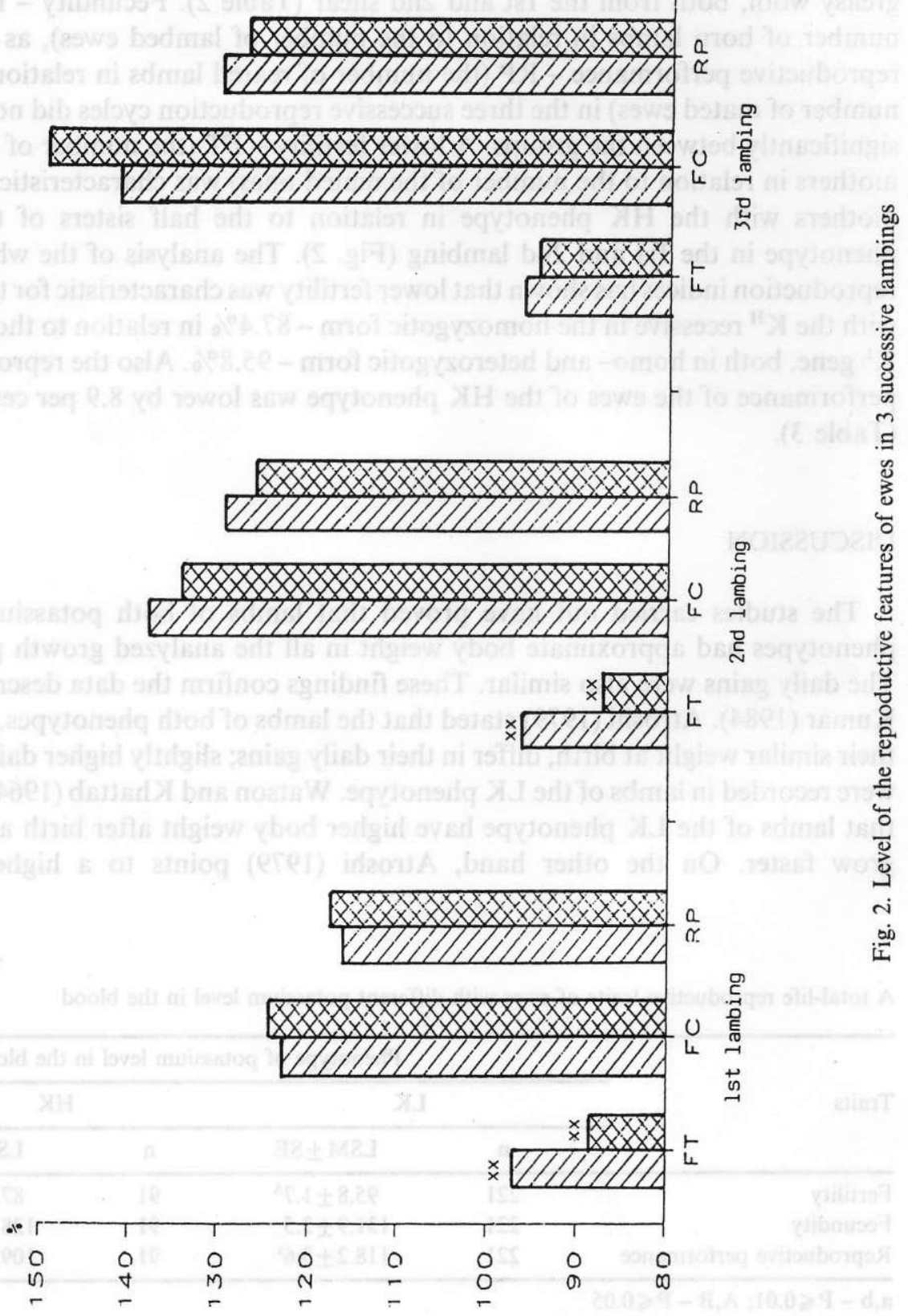


productivity in ewes of the LK phenotype. This, however, had not been confirmed in the present research.

The ewes of the Polish Lowland sheep of the HK phenotype were characterized by lower values of the reproduction features, i.e. fertility (FT) and reproduction performance (RP). Similar results were obtained by Atroshi (1979) and Dragnev and Tsvetanov (1963). The ewes of the HK phenotype better reared the lambs which has also been proved by Atroshi (1979) and Khattab et al. (1963). Lower reproduction performance (RP) of the ewes found in the present study was mainly caused by lower fertility and slightly lower fecundity. Reverse results were presented by Meyer et al. (1967), who pointed out the favourable effect of the HK phenotype on the reproduction performance.

\section{CONCLUSIONS}

The results obtained allow us to conclude that a high potassium level in the blood unfavourably affects the reproduction performance. However, the use of this trait as a genetic marker of the productivity needs to be supported by further similar research.

\section{REFERENCES}

Agar N.S., Evans J.V., Roberts J., 1972. Red blood cell potassium and haemoglobin polymorphism in sheep. Anim. Breed. Abstr. 40, 407-436

Atroshi F., 1979. Phenotypic and genetic association between production/reproduction traits and blood biochemical polymorphic characters in Finn shcep. Ann. Agric. Fenn. 19, (49), 2-85

Bhat P.N., Khan B.U., Santiago T.C., Sahni K.L., 1981. Potassium and haemoglobin polymorphism in Muzaffarnagari breed of sheep. Indian J. Anim. Sci. 51, 1055-1061

Bojczuk B., 1987. Genetic influence on the level of potassium in blood in sheep (in Polish). Ph. D. Thesis, High School of Education (WSP) Kielce, pp. 1-50

Dragnev D., Tsvetanov V., 1981. The concentration of potassium in the blood of sheep. 1. Breed differences in the concentration of potassium in erythrocytes (in Bulgarian). Zhiv. Nauki, Sofia $18,49-52$

Evans J.V., Harris H., Warren F.L., 1958. Hacmoglobin and potassium blood types in some non-British breeds. Nature, London $182,320-321$

Harvey W.R., 1987. Mixed model least-squares and maximum likelihood computer program. Ohio State University, pp. 1-59

Khattab A.G.H., Watson J.H., Axford R.F.E., 1963. Interrelations between blood potassium and haemoglobin in Welsh Mountain sheep. Anim. Prod. 5, 218-220

Kumar G.P.R., 1984. Genetic studies on haemoglobin and potassium polymorphism and their relationship with body weights in Bannur sheep. Anim. Breed Abstr. 52, abstr. 7240

Lazovski A.A., Spiridonov W.I., 1974. Genetic control of the potassium content in the erythrocytes of sheep (Ovis domesticus). Genetika 10, 48-54 
Lipecka C., Pięta M., Gruszecki T., 1987. Polymorphism of blood potassium in Polish Lowland sheep. Ann. UMCS, Sect. EE, Zoot. 5, 43-50

Lipecka C., Pięta M., Gruszecki T., 1991. Genetic polymorphism of blood potassium in various breeds and strains of sheep. Genet. pol. 32, 113-117

Meyer H., Lohse B., Grning M., 1967. Ein Beitrag zum Hämoglobin- und Blutkaliumpolymorhismus beim Schaf. Z. Tierzucht. ZüchtBiol. 83, 340-357

Watson J.H., Khattab A.G.H., 1964. The effect of haemoglobin and potassium polymorphism on growth and wool production in Welsh Mountain sheep. J. Agric. Sci., Camb. 63, 179-183

\section{STRESZCZENIE}

\section{Poziom potasu we krwi owiec a ich produkcyjność}

Badania przeprowadzono na owcach o wysokim i niskim poziomie potasu we krwi. Poziom potasu we krwi u pięciomiesięcznych jagniąt oznaczono i zwierzęta podzielono wg fenotypów: LH i HK. Badaniami objęto 871 jagniąt i 312 maciorek.

W testowanej populacji, częstotliwości występowania genu $\mathbf{K}^{11} \mathbf{u}$ jagniąt i maciorek wynosiła odp. 0,427 i 0,540 . Średni poziom potasu we krwi u 5-cio miesięcznych jagniąt dla fenotypów: HK $=30,5 \mathrm{mmol} / \mathrm{l} ; \mathrm{LK}=9,3 \mathrm{mmol} / 1$.

Wyniki wskazują również, że zwierzęta fenotypowo różne mają zbliżoną masę ciała: po urodzeniu $(5,1)$, w wieku $28(13,3 \mathrm{~g}), 100 \mathrm{dni}(30,0 \mathrm{~g})$ oraz 12 miesięcy $(72,3 \mathrm{~g})$. Maciorki miały podobne wydajności wełny zarówno przy pierwszej (ok. $4,5 \mathrm{~kg}$ ) jak i drugiej $(6,7 \mathrm{~kg}$ ) strzy rowadzonych w wieku 10 i 22 miesięcy. Istotnie mniejsza płodność i użytkowośc rozpłodową mialy maciorki o fenotypie IIK. 